\title{
The influence of timing and position of scion on graft take success of lemon
}

\author{
Muhammad Riaz Khan ${ }^{1 *}$, Farman Ghani ${ }^{1}$, Nadia Bostan ${ }^{2}$, Ghulam \\ $\mathrm{Nabi}^{1}$, Haji Muhammad ${ }^{3}$, Abid Ali ${ }^{1}$, Jalal Amin ${ }^{1}$ and Shah Khalid ${ }^{4}$ \\ 1. Department of Horticulture, The University of Agriculture, Peshawar- Pakistan \\ 2. Agricultural Research Institution, Swat, Khyber Pakhtunkhwa- Pakistan \\ 3. Agriculture Extension Office, Dargai, Khyber Pakhtunkhwa- Pakistan \\ 4. Department of Agronomy, The University of Agriculture, Peshawar- Pakistan \\ *Corresponding author's email: mriazkhan11@yahoo.com
}

Citation

Muhammad Riaz Khan, Farman Ghani, Nadia Bostan, Ghulam Nabi, Haji Muhammad, Abid Ali, Jalal Amin and Shah Khalid. The influence of timing and position of scion on graft take success of lemon. Pure and Applied Biology. Vol. 7, Issue 1, pp330-337. http://dx.doi.org/10.19045/bspab.2018.70040

Received: 03/11/2017 Revised: 12/02/2018 Accepted: 15/02/2018

Online First: 28/02/2018

\section{Abstract}

The Propagation of lemon (Citrus lemon L.) trees is possible by seed, cuttings, layering, budding and grafting. Grafting require compatible rootstock and scion wood. Keeping in view the importance of vegetative propagation in lemon the present research was designed to find out the most suitable time and grafting side for the successful T-grafting of lemon. This study was conducted at Jabban Agriculture Extension Department Dargai Malakand during the year 2015. The experiment was carried out in Randomized Complete Block Design (RCBD) with two factors, replicated three times. There were five treatments in each replication. The lemon were grafted on sour orang rootstock with three different time interval ( $21^{\text {nd }} \mathrm{June}, 29^{\text {th }} \mathrm{June}$, and $06^{\text {th }} \mathrm{July}$ ) and three grafting sides north, east and west. The results of study showed that all parameters were significantly affected by time interval and scion position. The mean values for graft direction shows early sprouting (28.1 days) was at east side, maximum graft length $(9.8 \mathrm{~cm})$, number of branches graft ${ }^{-1}(2.3)$ and number of leaves (12.6) at west side, maximum leaf area $\left(16.9 \mathrm{~cm}^{2}\right)$ at east side, while the mean values for the different grafting timing of the experiments shows early sprouting (29.1 days) at $29^{\text {th }}$ Jun, maximum graft length $(9.9 \mathrm{~cm})$, maximum number of leaves (11.9) and maximum number of branches graft ${ }^{-1}(2.0)$ at $6^{\text {th }} \mathrm{July,} \mathrm{maximum} \mathrm{leaf} \mathrm{area}\left(16.4 \mathrm{~cm}^{2}\right)$ at $29^{\text {th }}$ Jun. On the basis of statistical analysis and result first week of July and east direction significantly affected most of the observed parameters, so therefore it is recommended that the $1^{\text {st }}$ week of the month of July and east side is best for grafting in Lemon under the agro ecological conditions of Malakand valley Khyber Pakhtunkhwa.

Keywords: Graft success; Grafting time; Grafting side; Lemons (Citrus lemon L.)

\section{Introduction}

Lemons (Citrus lemon L.) are produced on a small evergreen tree that belongs to family Rutaceae which is a vast family and having numerous related genera included tangerine, citrange, orange, grapefruit, lime, and citron.
It is native to Asia and was introduced to Europe 1 A.D. Lemons are mostly produced commercially in China, Mexico, Brazil and Argentina [1] China is the main producing country in the world with $2,300,000$ million metric tons production. The average yield in 
Pakistan is far below than other citrus producing countries like Brazil where it is 40 to 60 tons $\mathrm{ha}^{-1}[2]$. Pakistan with respect to annual production of citrus fruits stands among the ten top citrus producing countries of the world. [3]. Lemons are good source of calcium, magnesium, Zinc, Manganese, Choline, potassium, iron, phosphorus, vitamin $\mathrm{C}$ and are eaten fresh or dried. Lemonade are well-liked beverages prepared by diluting the juices of these fruits and adding sugar [4]. The lemon forms a dispersal bush or a small tree, 3-6 m (10-20 feet) high if not pruned. Its young leaves have a distinctly reddish trace, later they turn green. some have sharp thorns at the axils of the leaves, the leaves of lemon are used in tea and cooked meats. The flowers have a sweet odor and are rather large; the petals are white above and reddish purple below. The fruit is oval with a broad, low, apical nipple and 810 segments. The white, spongy inner part of the peel, called the mesocarp, the seeds are small, ovoid, and pointed; occasionally, fruits are seedless. The pulp is unambiguously an acid. The predominant acid present is citric acid, which may amount to 5 percent or more by weight of the lemon's juice [5]. The storage life of lemon is very limited due to its perishable nature. In lemon fruit cold storage is commonly used to prolong the postharvest life by reducing fruit respiration rate, mass loss and general decay [6]. Storage temperatures can be regarded either as chilling, ranging from below 0 to $15^{\circ} \mathrm{C}$, or as freezing, ranging between -1.1 to $-0.6^{\circ} \mathrm{C}$ [6] The Propagation of lemon trees is possible by seed, cuttings, layering, budding or grafting. Budding and grafting require compatible rootstock and scion wood. Growing from seed, cuttings, or by layering is much easier for the average gardener to successfully manage. The basic aim the vegetative propagation is to multiply plants and genetically identical to their parent's. It is known from the recent highly density orchards are more productive which reduce the vigor of the plants accommodate more plants per unit area [7]. T-grafting is technique in which tissue from one plant is attached onto another plant. T-Grafting that gives a high success rate is most common methods used to propagate many fruits trees. Grafting time is also important factor to give high success rate; it must be performed during actively growing season in which the cambium cell intensely divides as the bark easily separates from the rootstock [8]. In Northwestern region of KPK these times ranges from end of May till beginning of June. Geographical sides also greatly affect graft success percentage. [9] found that graft union percentage at east direction is higher than the south direction.[9] Reported that east direction are more effective than the west and south direction which enhanced graft union. Citrus can be grown on wide range of soil but sandy loam and loamy soil is prep able. It can tolerate $\mathrm{pH}$ 5.5-6.5 these cannot continue growth below $13{ }^{0} \mathrm{C}$ and above $40^{\circ} \mathrm{C}$. Keeping in view the importance of vegetative propagation in lemon the present research was designed to study the influence of geographical sides and different timing of $\mathrm{T}$ grafting in lemon.

\section{Materials and methods}

The experiment entitled "The Influence of Timing and Position of Scion on Graft take success of lemon' was conducted at Jabban Agriculture Extension Department Dargai Malakand during the year 2015. To find out the most suitable time and best geographical side for successful graft take success in lemon. The experiment was laid out on Randomized complete Block Design (RCBD) with two factors. Total treatments were nine and each treatment was replicated three times. Factor A: Grafting time; $21^{\text {nd }}$ June at North, East, West, $29^{\text {th }}$ June at North, East, West and $06^{\text {th }}$ July at North, East, West. Factor B: Grafting position on rootstock; North, East and West. The sour orang 
rootstocks of same age having uniform diameter were selected and grafted with scion Lemons (Citrus lemon L.) the scion wood was prepared by clipping off the leaves leaving petiole stubs $0.5 \mathrm{~cm}$ long intact. Graft wood was $10 \mathrm{~cm}$ in length and taken from one year old branch and scion are T-grafted on 18 month old stocks seedling. Polythene sheet wrapped over the graft and both ends were tied with sun fiber covering the scion stock union. And all cultural practices were carried out regularly with all treatments. The following parameter were studied during the research, Days to sprouting, Graft length $(\mathrm{cm})$, Number of leaves graft $^{-1}$, Leaf area $\left(\mathrm{cm}^{2}\right)$, Number of branches graft ${ }^{-1}$.

\section{Statistical procedure}

All the data were recorded on plant growth parameters were to analysis of variance process to confirm differences among various grafting dates and sides. Least Significant Difference (LSD) test was used for mean differences where the results were significant. Data were analyzed while using statistical software "MSTATC" was used for calculating both ANOVA and LSD

\section{Results and discussion}

The experiment "Influence of timing and position of scion on the graft take success in lemon" data recorded on the following parameter are briefly explained as;

\section{Days to sprouting}

The analysis of variance for days to sprouting showed a significance variation of graft timing and direction while non-significant for their interaction. The mean values showed that, early sprouting of lemon graft were observed in plant grafted on $29^{\text {th }}$ Jun (29.1days), followed by on $06^{\text {th }}$ July (29.9 days) while late sprouting was observed at $21^{\text {th }}$ July 2015 (30.9 days). Early sprouting on $29^{\text {th }}$ Jun might be due to the fact that growth of grafts is influenced by various environmental factors of which temperature and relative humidity are most important. Beside these, rainfall, sunshine and light are also important for growth of grafts. Similar results are also reported by [9]. Comparing the means values of sprouting for geographical side, early sprouting of the of lemon graft was observed for plant grafted at east side (28.8 days followed by north side (29.7days) while late sprouting was noted for plant grafted at west side (31.4 days) (Table 1). [9] Reported that maximum graft sprouting and bud growth percentage in east direction. [9] The results are also supported by the findings that the early graft sprouting was observed in Jun at East side.

Table 1. Days to sprouting, graft length $(\mathrm{cm})$, number of leaves, leaf area and number of branches graft $^{-1}$ of lemon as effected by graft time and scion position

\begin{tabular}{|c|c|c|c|c|c|}
\hline Direction. & $\begin{array}{c}\text { Days to } \\
\text { sprouting }\end{array}$ & $\begin{array}{l}\text { Graft length } \\
(\mathrm{cm})\end{array}$ & $\begin{array}{c}\text { Number of } \\
\text { leaves }\end{array}$ & $\begin{array}{l}\text { Leaf area } \\
\quad(\mathrm{cm} 2)\end{array}$ & $\begin{array}{c}\text { Number of } \\
\text { branches } \\
\text { graft }^{-1}\end{array}$ \\
\hline North & $29.7 \mathrm{ab}$ & $5.8 \mathrm{~b}$ & $9.2 \mathrm{c}$ & $15.5 \mathrm{~b}$ & $1.6 \mathrm{~b}$ \\
\hline East & $28.8 \mathrm{~b}$ & $7.5 \mathrm{ab}$ & $10.8 \mathrm{~b}$ & $16.9 \mathrm{a}$ & $1.7 \mathrm{~b}$ \\
\hline West & $31.4 \mathrm{a}$ & $9.8 \mathrm{a}$ & $12.6 \mathrm{a}$ & $15.3 \mathrm{~b}$ & $2.3 \mathrm{a}$ \\
\hline LSD & 1.29 & 2.8 & 1.4 & 1.38 & 0.52 \\
\hline \multicolumn{6}{|l|}{ Time } \\
\hline $21^{\text {th }}$ June & $30.9 \mathrm{a}$ & $7.1 \mathrm{ab}$ & $10.1 \mathrm{~b}$ & $16.4 \mathrm{a}$ & 1.7 \\
\hline $2^{\text {th }}$ June & $29.1 \mathrm{~b}$ & $6.1 \mathrm{~b}$ & $10.6 \mathrm{ab}$ & $16.0 \mathrm{ab}$ & 1.9 \\
\hline $06^{\text {th }}$ July & $29.9 \mathrm{ab}$ & $9.9 \mathrm{a}$ & $11.9 \mathrm{a}$ & $15.4 \mathrm{~b}$ & 2.0 \\
\hline LSD & 1.29 & 2.8 & 1.4 & 1.38 & 0.52 \\
\hline $\mathrm{N} \times \mathrm{C}$ & Figure 1 & Figure 2 & Figure 3 & Figure 4 & Figure 5 \\
\hline
\end{tabular}




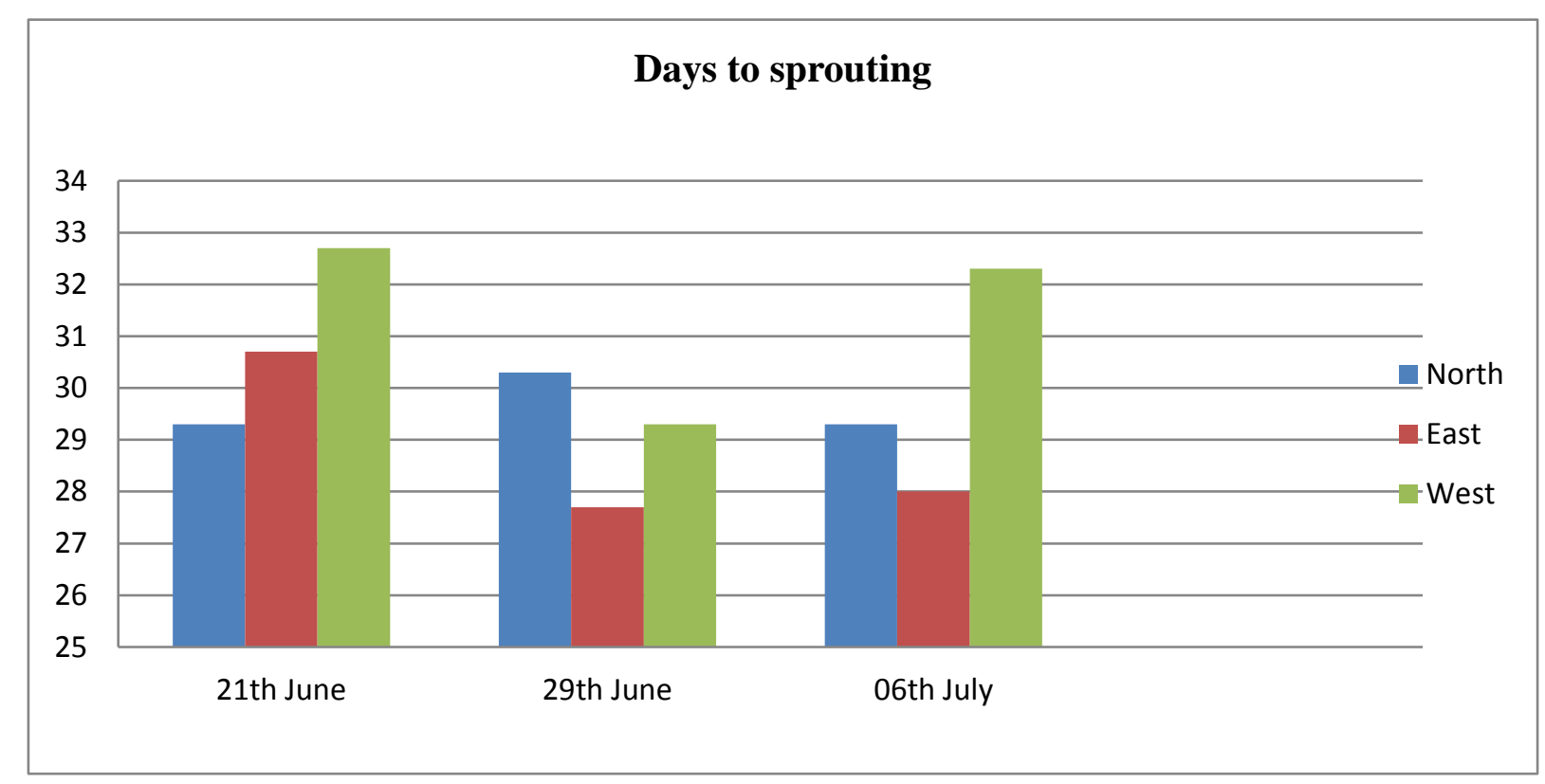

Figure 1. Days to sprouting

\section{Graft length (cm)}

The analysis of variance showed a significance variation of timing and direction on graft length while their interaction was found non-significant. Means of data for time showed that maximum graft length were observed on $6^{\text {th }}$ July $(9.9 \mathrm{~cm})$, followed by $21^{1 \text { st }}$ Jun $(7.1 \mathrm{~cm})$, while minimum graft length were observed on 29 Jun $(6.1 \mathrm{~cm})$. The maximum graft length might be due to prevailing suitable climatic condition along with availability of dormant and swollen terminal buds of scion in bulging condition which encouraged earlier sprouting and their continual growth. Budding performed well in the seasons when rootstock have active growth and cambium cells intensely divide as the skin easily separates from wood. Similar results were also found by [10]. In case of direction maximum graft length was produced by grafts at west direction $(9.8 \mathrm{~cm})$, followed by grafts grafted at east direction $(7.5 \mathrm{~cm})$.While the north direction produced the minimum graft length of $(5.8 \mathrm{~cm})$ (Table $1)$. The results are also in similarities with the findings of $[11,12]$ who stated that attentive to continuous sunlight radiation at west direction has been good for graft and bud union as well as growth as until sundown in west direction, probably increase temperature.

\section{Number of leaves graft ${ }^{-1}$}

Number of leaves graft ${ }^{-1}$ was significantly influenced by timing and direction while interaction was found non-significant. Mean value of table showed that the maximum number of leaves graft $^{1}$ was found grafts grafted on 6 July (11.9), followed by 29 Jun (10.6), while minimum number of leaves graft $^{-1}$ was produced by graft that was grafted on $21^{1 \text { st }}$ Jun (10.1). Maximum number of leaves graft $^{-1}$ might be due to favourable ambience and humidity which accelerated early bud breaking and thus secondarily influence on maximum leaf flushing as well as maximum number of leaves. [13] Reported that grafting performed in month of July produced highest number of leaves. Number of leaves graft $^{-1}$ however, obtained through grafting performed in June decreased severely. In case of direction maximum number of leaves graft ${ }^{-1}$ was found on grafts 
grafted at west side (12.6), followed by east side (10.8), while minimum number of leaves graft $^{-1}$ was observed at north side (9.2)
(Table 1). The results are in agreement with the findings of [14] who reported significant effect of graft direction on number of leaves.

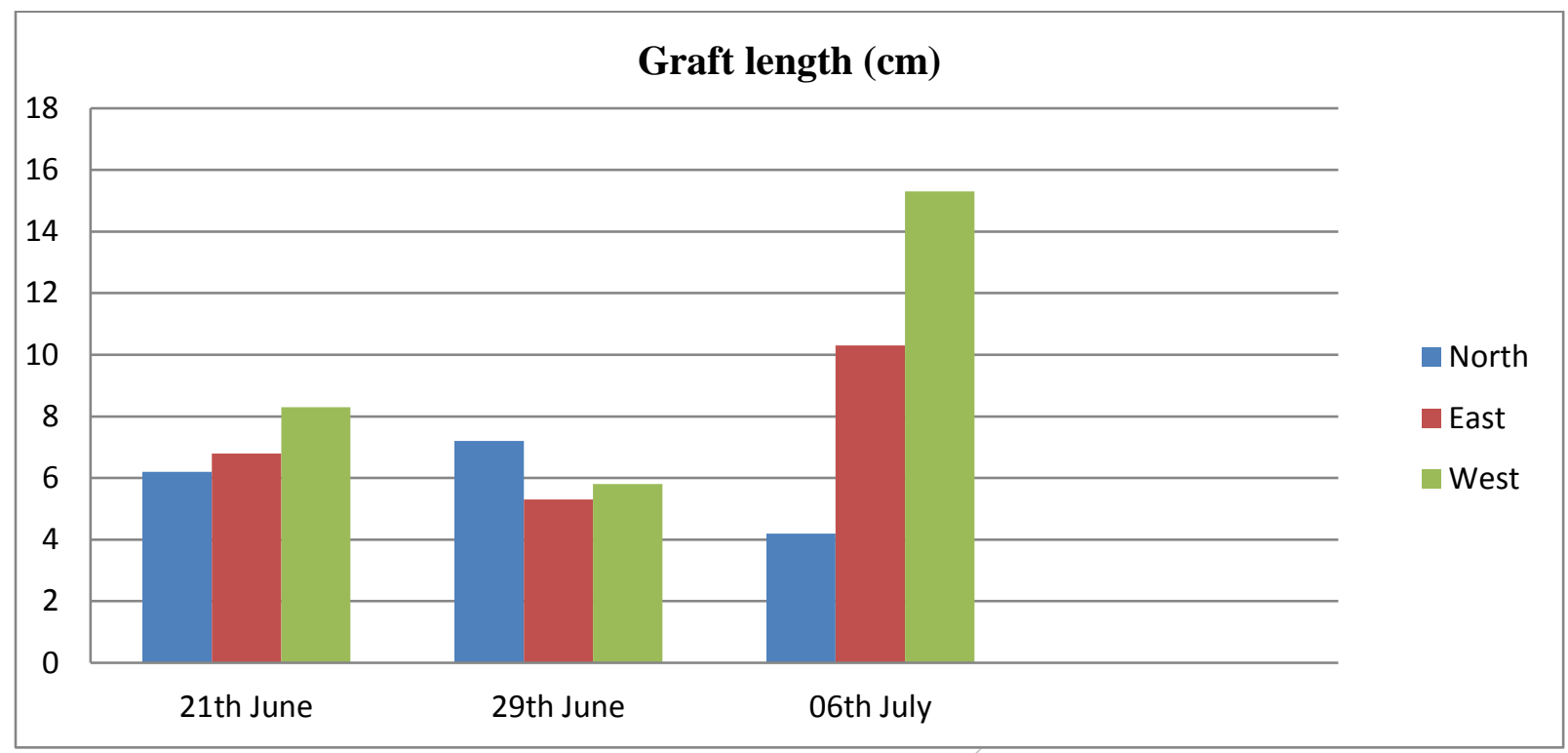

Figure 2. Graft length $(\mathrm{cm})$

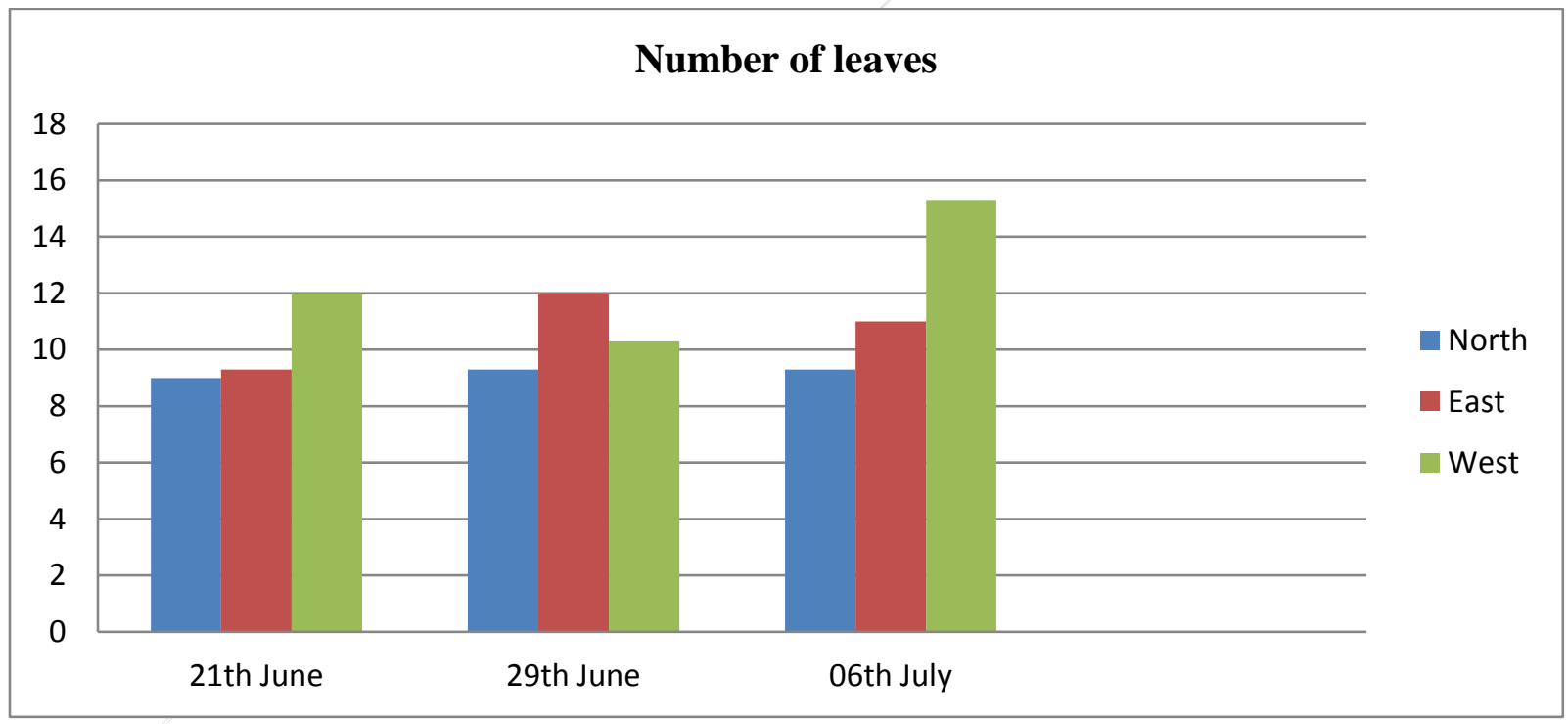

Figure 3. Number of leaves

\section{Leaf area graft ${ }^{-1}\left(\mathrm{~cm}^{2}\right)$}

Statistical analysis of data showed that leaf area was significantly influenced by graft time and direction while its interaction was found non-significant. Mean value indicated that maximum leaf area graft ${ }^{-1}$ was observed in plants grafted at $21^{\text {st }}$ June $\left(16.4 \mathrm{~cm}^{2}\right)$, followed by 29 Jun $\left(16 \mathrm{~cm}^{2}\right)$, while minimum leaf area graft $^{-1}$ was observed from the graft grafted on $6^{\text {th }}$ July $\left(15.4 \mathrm{~cm}^{2}\right)$. In case of direction maximum leaf area graft $^{-1}$ were observed from the graft grafted at east side $\left(16.9 \mathrm{~cm}^{2}\right)$, followed by north side $\left(15.5 \mathrm{~cm}^{2}\right.$, 
while minimum leaf area graft $^{-1}$ were observed from the plants grafted at west side $\left(15.3 \mathrm{~cm}^{2}\right)$ (Table 1). Present results are in line with the findings of [15] they reported that grafting time and geographical sides had significant effect on leaf area graft ${ }^{-1}$.

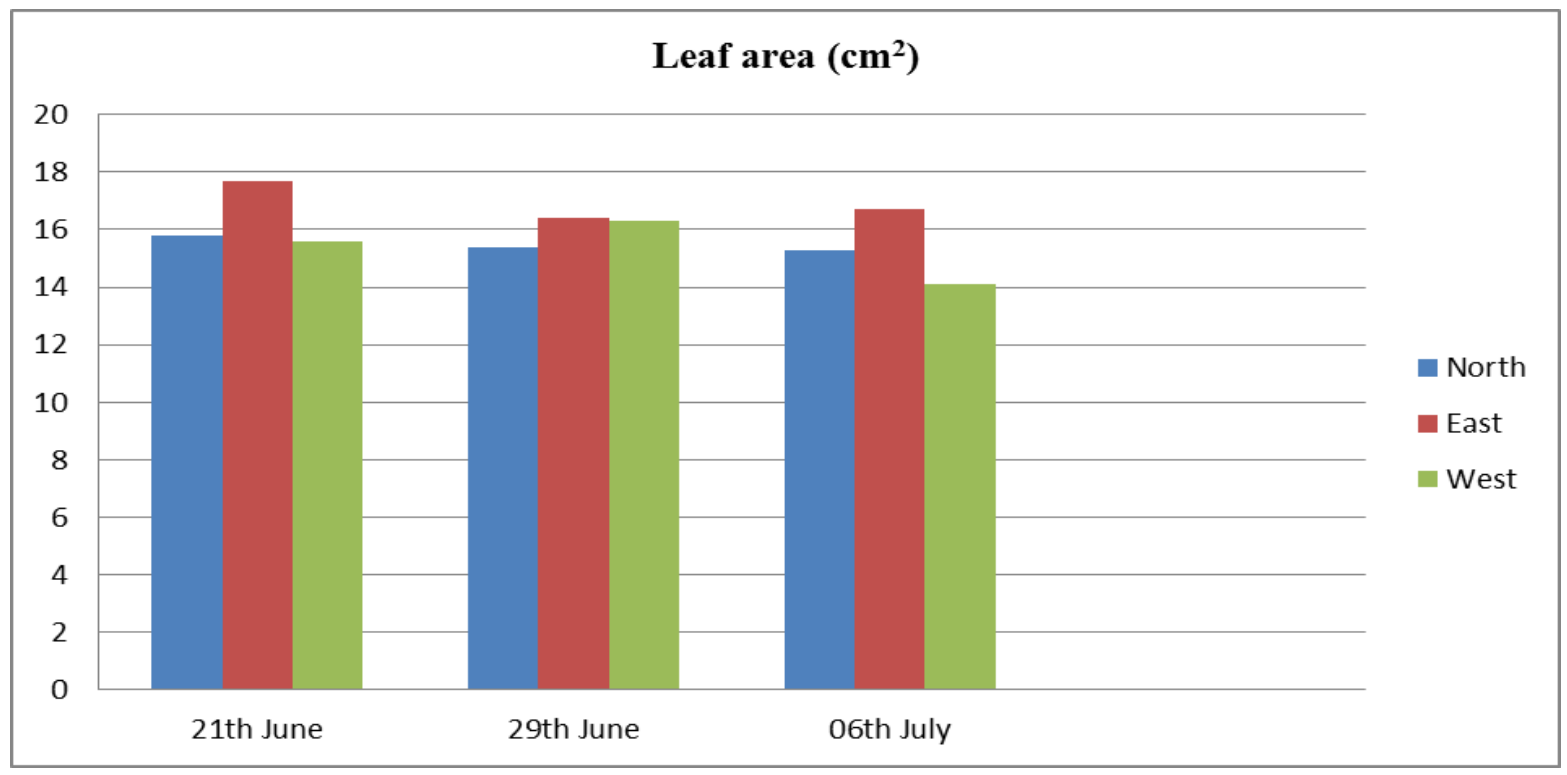

Figure 4. Leaf area $\left(\mathrm{cm}^{2}\right)$

\section{Number of branches graft ${ }^{-1}$}

The analysis data showed that number of branches graft $^{-1}$ was significantly influenced by grafting time and directions while nonsignificantly affected by their interaction. Effect of time's interval indicated that maximum number of branches graft $^{-1}$ was found on grafts grafted at 6 July (2), followed by 29 Jun (1.9), while grafts those were grafted on $21^{\text {st }}$ Jun produced minimum number of branches graft ${ }^{-1}$ (1.7). Maximum number of branches might be due to the supply of proper amount of food materials, produced by the leaves with the intervals of time. In case of direction maximum number of branches graft $^{-1}$ were found in plants grafted at west side (2.3), followed by east side (1.7). While minimum numbers of branches graft-1 were produced in plants grafted at north side (1.6) (Table 1). The results are similar to the studies of [14] who reported significant effect of grafting time on number of branches graft ${ }^{-1}$. 


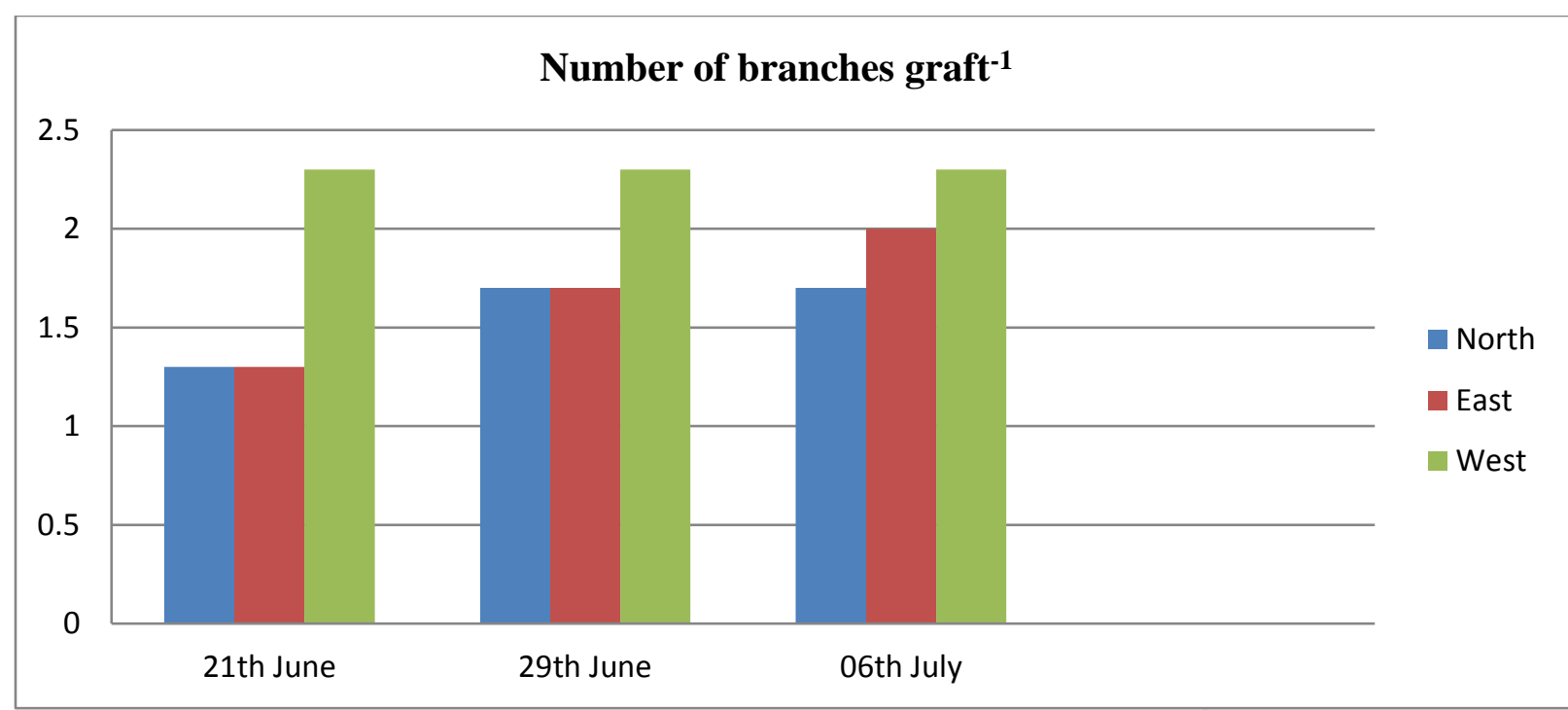

Figure 5. Number of branches graft ${ }^{-1}$

\section{Conclusions}

This experiment concluded that among different dates and geographical site of grafting, most of the parameters exhibited better performance to date $6^{\text {th }}$ of July at east side. So it is concluded from the experiments that best time for grafting of lemon in month of July at east direction in the agro-climatic condition of Malakand region.

\section{Authors' contributions}

Conceived and design the experiment: $\mathrm{N}$ Bostan, Performed the Experiments: MR Khan, Analyzed the Data: MR Khan \& F Ghani, Contributed reagents/ materials/ analysis tools: MR Khan \& F Ghani, Wrote the paper: MR Khan

\section{References}

1. Kiecolt G \& Janice K (2008). Chemical composition of lemon. J Applied Sci Res 33(3): 328-39.

2. Ibrahim M, Abbasi, NA, Rehman H, Hussain Z \& Hafiz, IA (2011). Phenological behavior and effect of different chemicals on pre-harvest fruit drop of Sweet orange Salustiana. Pak J Bot 43: 453-457.

3. Khan SRA. (2005). Citrus quality to meet global demand. Pakistan agriculture overview,http://www.pakistan.com/englis h/agri.overview/index.shtml.

4. Hofrichter M \& Springer P (2010). Industrial applications of lemons pp 224.

5. Wang CY \& Wallace HA (2004). Chilling and freezing injury. Int J Agri 54:12-15.

6. Maul P, McColluma G, Guy CL \& Porat $\mathrm{R}$ (2011). Temperature conditioning alters transcript abundance of genes related to chilling stress in 'Marsh' grapefruit flavedo. Post-harvest Biol and Technology 60: 177-185.

7. Mir M \& Kumar (2011). Effect of different methods, time and environmental condition on grafting in walnut. Int Farm Sci 1(2): 17-22.

8. Hansen CJ \& Hartman HT (1951). Influence of various treatments given to walnut graft on the percentage of scion growing. Proc. Amer. Soc Hort Sci 57: 97193.

9. Rafiei J, Aboutalebi A \& Behrooznam. B (2013). Study on the effect of time, geographical side and color of wrapping materials on graft union percentage and scion growth of three commercial citrus cultivars on Macian lime rootstock. Inter Res J Appl Sci 4(2): 316-320. 
10. Khoshkhui M (1989). Plant propagation, principles and practices. Vol. 1\&2. Shiraz University Press, Iran.

11. Hartman HT \& Hansen CJ (1951). Influence of various treatments given to Walnut graft on the percentage of scions growing. Proc Amer Soc Hort Sci 57: $97-$ 193.

12. Zenginbal H, Eluk H, Ozcan M (2003). The effect of tying and wrapping materials and their color on budding success in Kiwifruit in Turkey. J Agric Sci 6: 119-124.

13. Rayya A, Kasim MS, Shaheen MA, Yehia TA \& Ali EL (2009).
Morphological and anatomical evaluation of different budding and grafting methods and times of neplus ultra almond cultivar. $J$ of Applied Sci Res 5(3): 253-262.

14. Vatankhah M, Jafarpour M \& Shams D (2015). Effect of time, method of budding and type of scion on bud take of sour cherry scions onto mahaleb rootstocks. Int J Agro Agri Res 6(4): 233-239.

15. Hibber $\mathrm{H}$, Framptom $\mathrm{J}$ \&Blazich $\mathrm{A}$ (2010). Effect of Grafting Date, Shade and Irrigation. Hort Sci 45(4): 617-620. 